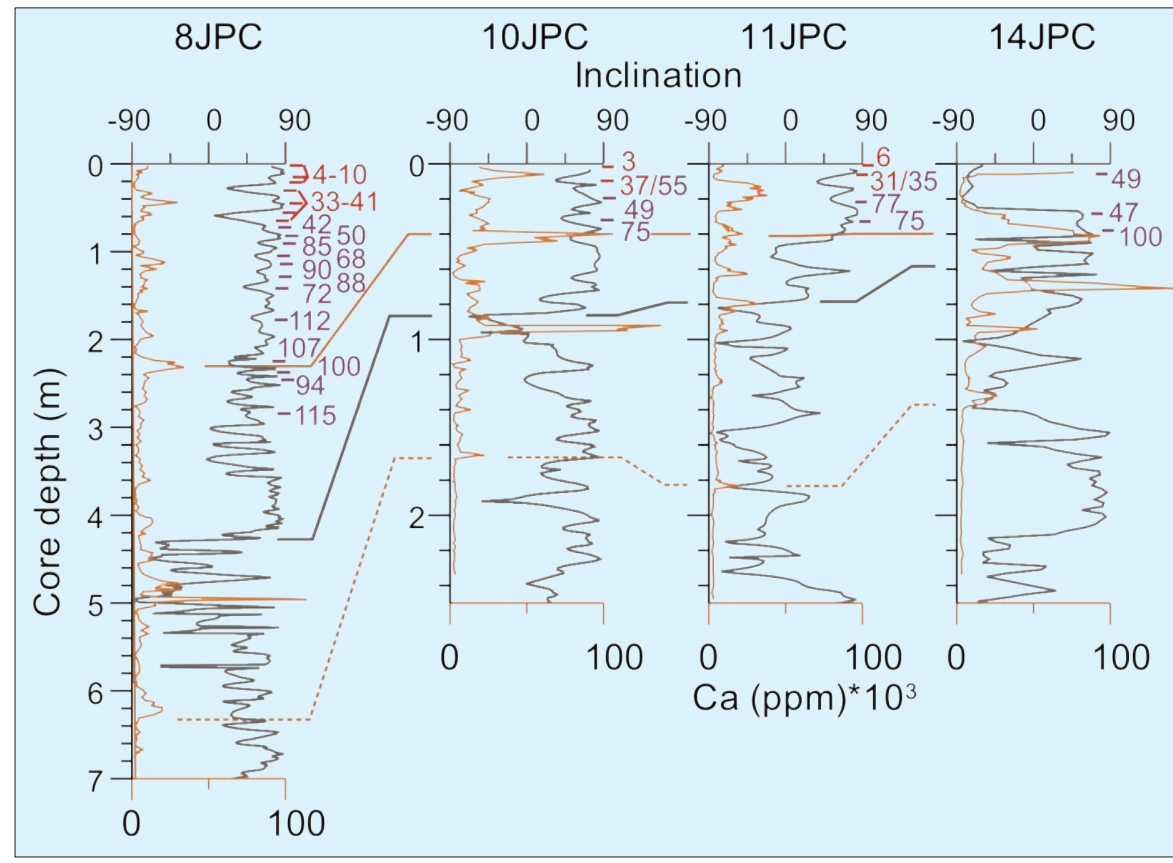

Figure 2: Correlation of paleomagnetic inclination (gray plots) and detrital carbonates (XRF Ca content; orange plots) for upper parts of HOTRAX cores 8, 9, 10 and 14JPC from Mendeleev-Alpha Ridges, south to north (see Fig. 1 for core location) (from Polyak et al., in review). Correlation lines are shown for a prominent carbonate layer at ca. MIS 5/6 boundary (orange), prominent inclination drop within MIS 7 (gray), and base of detrital carbonate deposition (dashed orange). Radiocarbon and amino-acid racemization ages (kyr) are shown in red and purple, respectively. Radiocarbon ages in core HLY0503-8JPC are grouped for simplicity. Note a two-fold change in core depth scale between southern and northern Mendeleev Ridge cores (i.e., between cores 8JPC and 10JPC).

sity fluctuations dated elsewhere from global and regional datasets. These papers also reveal the problems with dating Arctic sediments, in particular dissolution and uncertain reservoir corrections that might even change during the Holocene due to the influence of differing water masses on some slope areas.

Other papers deal with depositional changes in the Holocene and processes responsible for the extremely high sedimentation rates along the Alaskan margin. The important role of sea-ice transport and deposition of sediment in the Arctic is generally accepted but there are still many questions remaining, e.g., just how important sea ice melt-out is to the deposits in various parts of the Arctic. In the GPC HOTRAX issue a number of papers based on cores from the central Arctic Ocean with longer stratigraphy and lower sedimentation rates provide new stratigraphic constraints, especially for the Upper Quaternary, and correlate records between areas with different depositional environments.

Figure 2 exemplifies the correlation of cores along the Mendeleev and Alpha Ridges, based on normal remanent mag- netization (NRM) records, along with distribution of detrital carbonates (indicated by Ca concentrations), and radiocarbon and amino-acid racemization (AAR) dates. Being overall much lower than on the Alaskan margin, sedimentation rates in the central Arctic appear to change dramatically, from nearly a hiatus in some areas during the height of glacial intervals to several $\mathrm{cm} /$ kyr during deglaciations and interglacial intervals. In addition to HOTRAX materials, the GPC special issue presents related data from the Siberian seas and modeling results of the MIS6 glaciation-potentially the biggest ice sheet in the history of the Eurasian Arctic.

\section{Note}

Data from this research is being archived at the Joint Office for Science Support at the University of Colorado. Metadata on the HOTRAX collection are posted on the NGDC MGG website (www.ngdc.noaa.gov/mgg/curator/curator. html).

\section{References}

Bond, G., Broecker, W., Johnsen, S.J., McManus, J., Labeyrie, L., Jouzel, J. and Bonani, G., 1993: Correlations between climate records from North Atlantic sediments and Greenland ice, Nature, 365 143-147.

Calder, C.A., Craigmile, P.F. and Mosley-Thompson, E., 2008: Spatial variation in the influence of the North Atlantic Oscillation on precipitation across Greenland, Journal of Geophysical Research, 113:D06112, doi.1029/2007JD009227

Darby, D.A., 2008: The Arctic perennial ice cover over the last 14 million years, Paleoceanography, 23: PA1507, doi:10.1029/2007PA001479

Jakobsson, M., Macnab, R., Mayer, L., Anderson, R., Edwards, M., Hatzky, J., Schenke, H.W. and Johnson, P., 2008: An improved bathymetric portrayal of the Arctic Ocean: Implications for ocean modeling and geological, geophysical and oceanographic analyses, Geophysical Research Letters, 35: L07602.

Polyak, L., et al., in review: Late Quaternary stratigraphy and sedimentation patterns in the western Arctic Ocean, Global and Planetary Change.

\title{
Lake El'gygytgyn's emerging IPY record of Pliocene to recent Arctic change
}

\author{
Julie Brigham-Grette ${ }^{1}$, M. Melles², P. Minyuk ${ }^{3}$, C. Koeberl ${ }^{4}$ and Science Party \\ 'Department of Geosciences, University of Massachusetts, Amherst, USA; juliebg@geo.umass.edu \\ ${ }^{2}$ Institute of Geology and Mineralogy, University of Cologne, Germany; ${ }^{3}$ North-East Interdisciplinary Scientific Research Institute, Magadan, Rus- \\ sia; ${ }^{4}$ Department of Geological Sciences, University of Vienna, Austria \section{effort to collect the complete paleoclimate archive from this region back to 3.6 Myr ago.} \\ Lacustrine sediments representing the last 3 glacial cycles from NE Russia chronicle the magnitude and \\ dynamics of millennial-scale change across the western Arctic. Logistics are now underway in a multi-national
}

Imagine looking at a circum-Arctic map of northern hemisphere glacial ice extent and being given the opportunity to select an ideal setting where one might record an undisturbed time-continuous terrestrial record of Arctic climate change. Unprecedented, Lake El'gygytgyn (pronounced el'geegitgin), is such a place, formed by astrophysical chance 3.6 Myr ago, when a meteorite struck Earth $100 \mathrm{~km}$ north of the Arctic Circle in Chukotka on the drainage divide between the Arctic Ocean and the Bering Sea (Layer, 2000) (Fig. 1).

When the meteorite hit, the middle Pliocene Arctic was exceedingly different from today, with mean annual tem- peratures estimated at $12^{\circ} \mathrm{C}$ warmer and global averages $3-4^{\circ} \mathrm{C}$ warmer than today (Dowett, 2007; Saltzman et al., 2008). At that time, most of the Arctic borderlands were heavily forested, the Arctic Ocean lacked permanent sea ice, and the Greenland Ice Sheet did not exist, at least in its present form (Brigham-Grette and Carter, 
1992; Miller and Brigham-Grette et al., in press). In fact, after the impact, a million years passed before onset of the first major glaciation of the northern hemisphere (Haug et al., 2005). The El'gygytgyn Crater measures $\sim 18 \mathrm{~km}$ in diameter and lies nearly in the center of what was to become Beringia-the largest contiguous landscape in the Arctic to have escaped continental-scale glaciation. Within the crater rim today, Lake El'gygytgyn measures $12 \mathrm{~km}$ in diameter and is $170 \mathrm{~m}$ deep, enclosing 350-400 m of sediment deposited since the time of impact (Gebhardt et al., 2007).

\section{Deep Drilling Initiation}

After several years of preparation, pre-site survey work and arduous logistical planning, Lake El'gygytgyn is now the focus of a challenging interdisciplinary multinational drilling campaign that is part of the International Continental Drilling Program (ICDP). With drilling initiated in November 2008, the goal is to collect the longest time-continuous record of climate change in the terrestrial Arctic, and to compare this record with those from lower latitude marine and terrestrial sites to better understand hemispheric and global climate change. Coring objectives include replicate overlapping lake sediment cores of $330 \mathrm{~m}$ and $420 \mathrm{~m}$ length at 2 sites (D1 and D2 in Fig. 1; four cores total) near the deepest part of the lake. Coring shall be continued $300 \mathrm{~m}$ (D1) and $100 \mathrm{~m}$ (D2) into the underlying impact breccia and brecciated bedrock, in order to investigate the impact process and the response of the volcanic bedrock to the impact event. One additional land-based core (site D3, lake shore) to $\sim 200 \mathrm{~m}$ in lake sediments now overlain by frozen alluvial sediments will allow better understanding of sediment supply to the lake and spatial depositional heterogeneity since the time of impact. This latter drill site at the west edge of the lake outside the talik (unfrozen ground in an area of permafrost) will also be used for permafrost studies and be permanently instrumented for future ground temperature monitoring, as part of the Global Terrestrial Network for Permafrost (www. gtnp.org/). Drilling of the primary D1 and D2 sites will take place from February to the middle of May 2009, using the lake ice as a drilling platform. The project is using a new GLAD-800 drilling system modified for extreme weather conditions by Drilling, Observation and Sampling of the Earths Continental Crust Inc. (DOSECC). Moreover, the science and logistics involves close cooperation with the Russian Academy of Sciences (Far East Geological

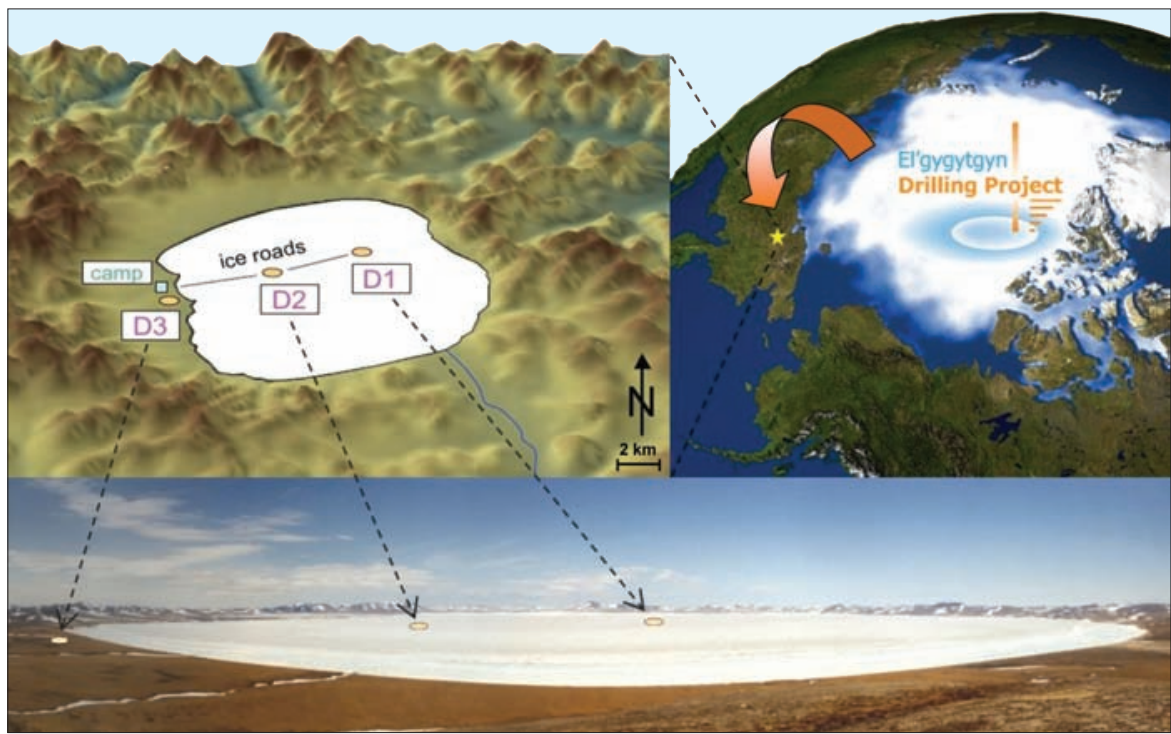

Figure 1: Top right: Location of Lake El'gygytgyn at $67.5^{\circ} \mathrm{N}$ and $172^{\circ} \mathrm{E}, \sim 100 \mathrm{~km}$ north of the Arctic Circle in Chukotka, NE Russia (base map courtesy of Arctic Climate Impact Assessment). Top left: Digital elevation model (Conrad Kopsch, AWI) with drill site locations, projected onto a panoramic view of Lake El'gygytgyn (bottom) taken in May, facing north (Volker Wennrich, Cologne).

Institute, Vladivostok; and Northeast Interdisciplinary Scientific Research Institute, Magadan) and Roshydromet's Arctic and Antarctic Research Institute, St. Petersburg.

In summer 2009, the cores will be flown by chartered cargo plane to St. Petersburg. Later they will be trucked to the University of Cologne, Germany, where sub-sampling by the international team and their students will start in September. The archive core halves will be shipped to the University of Minnesota LacCore Facility, USA for post-moratorium studies.

\section{Pilot Cores and Initial Results}

The impetus for deep drilling at Lake El'gygytgyn is largely based on field and laboratory studies carried out over the past decade. Seismic work in the lake and morphostratigraphic work in the catchment and surrounding region confirmed that the lake record was undisturbed, without evidence of glaciation or desiccation (Niessen et al., 2007; Glushkova and Smirnov, 2007). A 12.9-m-long sediment core retrieved from the deepest part of the lake in 1998 revealed a basal age of $\sim 250$ kyr and demonstrated, using a variety of proxies, the sensitivity of this lacustrine environment to record high-resolution climate change across NE Asia at millennial timescales (Brigham-Grette et al., 2007; Melles et al., 2007; Nowacyzk et al., 2007; Forman et al., 2007; plus 7 other papers in same issue; Fig. 2). A 16.7-m-long sediment core taken nearby in 2003 dated to nearly $300 \mathrm{kyr}$ and confirmed the reproducibility of the record (Juschus et al., 2007). This research also showed that nearly every proxy can be systemically linked to changes in the duration of seasonal lake ice cover, regional temperature, and changes in hy- drologic input driven largely by high latitude precessional cycles and feedbacks. For example, the magnetic susceptibility and sedimentology showed that perennial ice cover during glacial summers led to anoxia in the hypolimnion (bottom layer in a thermally stratified lake), which had a profound impact on the biogeochemistry at the sediment/water interface (Nowacyzk et al., 2007; Minyuk et al., 2007). Knowledge of the basin geomorphology and sedimentation processes informs us of likely changes in landscape weathering and sedimentation rates (Asikainen et al., 2007; Glushkova and Smirnov, 2007). We have also demonstrated that while gravitational sediment transport occurs in the basin, such events do not cause erosion of the continuous stratigraphy in the center of the lake where drilling is planned. Documenting the dynamics and controls on the lake's seasonal ice cover (Nolan et al., 2003; Nolan and Brigham-Grette, 2007) has been key to understanding lake Moreover, this work has been critical to developing safety plans for ice thickening and engineering prior to drilling from the lake's frozen surface.

\section{Potential Implications}

Our ability to inform policy makers about global/regional climate and related environmental change and its uncertainties depends on our capacity to understand the role of the Arctic region in modulating past periods of change under different climate forcing conditions. Of prime interest to the scientific community is determining why and how the Arctic climate system evolved from a warm forested ecosystem into a cold permafrost ecosystem between 2-3 Myr ago. A continuous depositional circulation and beach geomorphology. 


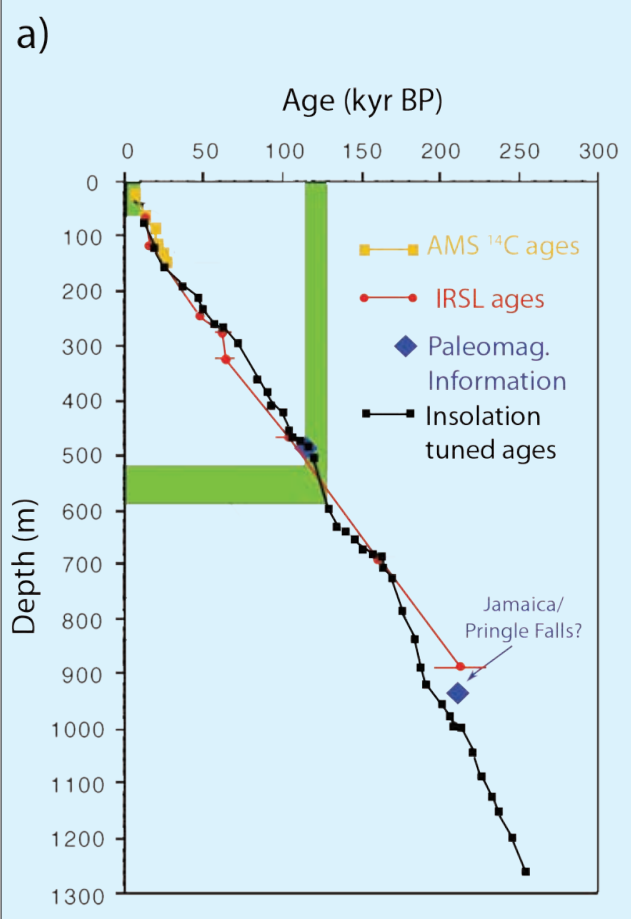

b)

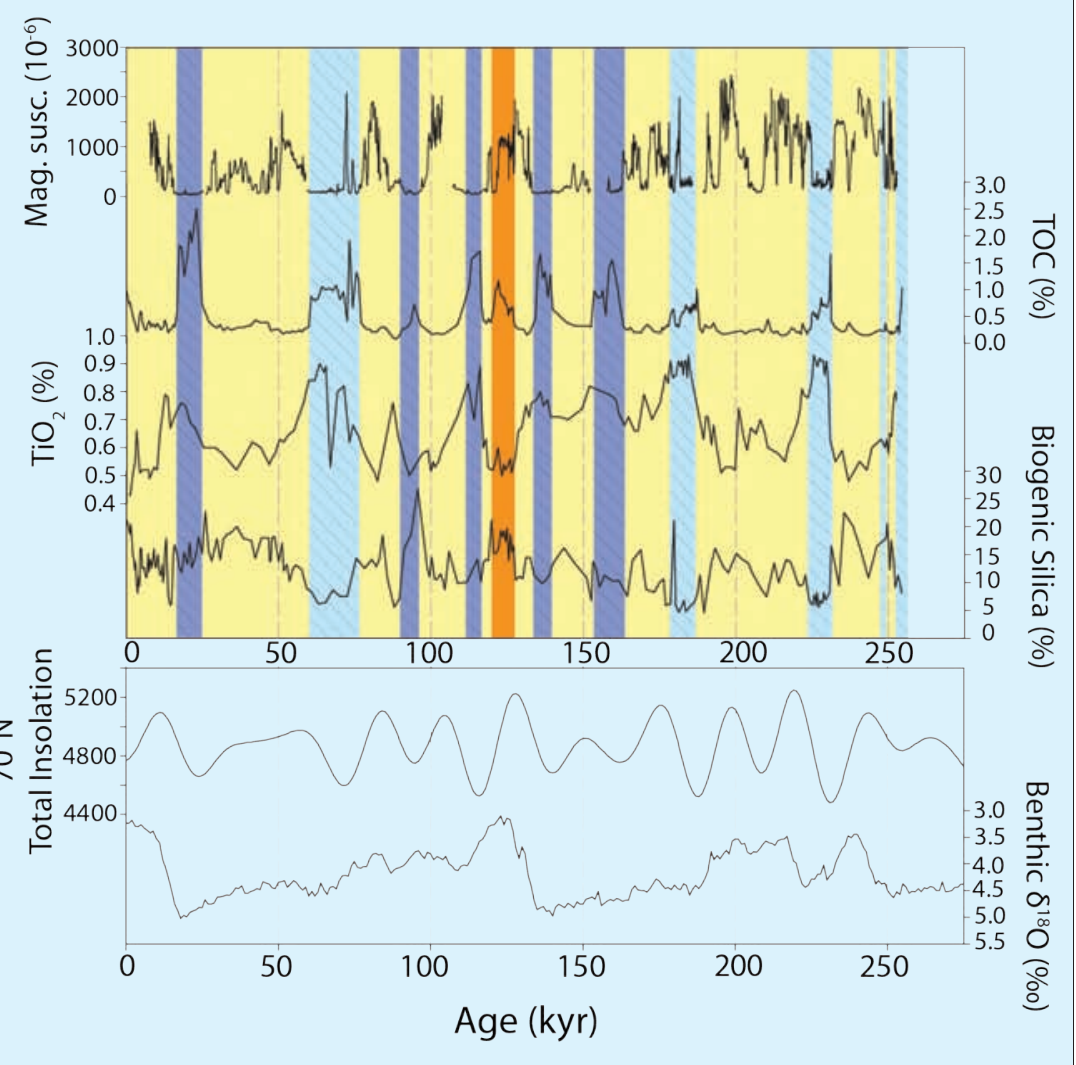

Figure 2: The age model of core PG1351 (taken next to D1, Fig. 1) from Lake El'gygytgyn based on radiocarbon ages, infrared stimulated luminescence ages (IRSL), paleomagnetics and interglacial pollen assemblages (Forman et al., 2007; Nowacyzk et al., 2002; 2007; Lozhkin et al., 2007). a) Green bars represent the warmest portion of the last interglacial (MIS 5e) and the Holocene. The black line represents the revised orbitally-tuned chronology based on precession (Nowacyzk et al., 2007). b) High-resolution proxies (magnetic susceptibility, total organic carbon (TOC), Titanium Dioxide (TiO2), and biogenic silica) strongly controlled by temperature, productivity, hydrology, and variability in seasonal lake ice cover. During colder intervals (cold and moist - blue; cold and dry - purple) sediments are laminated when the lake remains ice covered in summer, ventilation ceased, and bottom waters became anoxic; warmer intervals (warm-yellow; peak warm - orange) are marked by non-laminated sediments, suggesting lake ventilation during open water summers (see climate modes of Melles et al., 2007). These proxies are plotted against the age model, insolation (Berger and Loutre, 1991) and the benthic $\partial^{18} \mathrm{O}$ stack of Lisiecki and Raymo (2005). Figure produced by Kenna Wilkie.

record in this unique lake will provide a means of capturing the mechanisms and dynamics of glacial/interglacial and millennial-scale change from this region over the duration of the " 41 kyr world" and late Cenozoic "100 kyr world". This record will then be compared with other long records from around the world but especially the low-latitude ocean records, to evaluate polar amplification, model systemic teleconnections and leads/lags relative to insolation forcing. This record will also provide insight into whether rapid change events identified during the last glacial cycle are typical of earlier glacial periods. We hope to provide the science community with an understanding of the poorly documented regional sensitivity of the NE Asian Arctic to millennial-scale abrupt change (Heinrich and D/O scale) and interglacial warmth detected at global vs. regional scales, within the timeframe of the
EPICA ice cores, long Asian loess and lake records, and comparable marine records. Climate modeling is also an important aspect of the program in allowing these relationships to be evaluated systematically.

\section{Note}

All data produced by the project will be stored with NOAA/NGDC (www.ncdc.noaa.gov/paleo/ paleo.html) and PANGAEA/WDC-MARE (www. pangaea.de/).

\section{Acknowledgements}

The Lake El'gygytgyn Drilling Project is an international effort funded by ICDP, the US National Science Foundation Earth Sciences Division and Office of Polar Programs, the German Federal Ministry for Education and Research (BMBF), Alfred Wegener Institute, and GeoForschungsZentrum-Potsdam, and the Russian Academy of Sciences Far East Branch. The leading Russian institutions include Roshydromet's Arctic and Antarctic Research Institute, the Northeastern Interdisciplinary Scientific Research Institute, and the Far East Geological Institute. The deep drilling system for Arctic operations was developed by DOSECC, Inc.

\section{References}

Brigham-Grette, J., Melles, M., Minyuk, P. and Scientific Party, 2007: Overview and Significance of a $250 \mathrm{ka}$ Paleoclimate Record from El'gygytgyn Crater Lake, NE Russia, Journal of Paleolimnology, 37: 1-16.

Gebhardt, A.C., Niessen, F. and Kopsch, C., 2006: Central ring structure identified in one of the world's best-preserved impact craters, Geology, 34: 145-148.

Melles, M., Brigham-Grette, J., Glushkova, O.Yu., Minyuk, P.S., Nowaczyk, N.R. and Hubberten, H.W., 2007: Sedimentary geochemistry of a pilot core from Lake El'gygytgyn - a sensitive record of climate variability in the East Siberian Arctic during the past three climate cycles, Journal of Paleolimnology, 37: 89-104.

Nowaczyk et al., 2002: Magnetostratigraphic results from impact crater Lake El'gygytgyn, northeastern Siberia: A 300 kyr long high resolution terrestrial paleoclimatic record from the Arctic, Geophysical Journal International, 150: 109-126.

Nowaczyk N.R., Melles, M. and Minyuk, P., 2007: A revised age model for core PG1351 from Lake El'gygytgyn, Chukotka, based on magnetic susceptibility variations correlated to northern hemisphere insolation variations, Journal of Paleolimnology, 37: 65-76.

For full references please consult:

www.pages-igbp.org/products/newsletters/ref2009_1.htm

\section{Looking for a job in paleoscience?}

\section{Try the PAGES free Jobs Database!}

All the international paleoscience jobs from listservers in the one place. Browse or add jobs at: www.pages-igbp.org/resources/jobs/ 